\title{
The Freedmen's Memorial to Lincoln: A Postscript to Stone Monuments and Flexible Laws
}

J. Peter Byrne

Georgetown University Law Center, byrne@law.georgetown.edu

This paper can be downloaded free of charge from:

https://scholarship.law.georgetown.edu/facpub/2304

https://ssrn.com/abstract=3678685

J. Peter Byrne, The Freedmen's Memorial to Lincoln: A Postscript to Stone Monuments and Flexible Laws, forthcoming in the Florida Law Review Forum.

This open-access article is brought to you by the Georgetown Law Library. Posted with permission of the author. Follow this and additional works at: https://scholarship.law.georgetown.edu/facpub

Part of the Property Law and Real Estate Commons, and the Public Law and Legal Theory Commons 
The Freedmen's Memorial to Lincoln: A Postscript to Stone Monuments and Flexible Laws

J. Peter Byrne

In a recent essay in the Florida Law Review Online, commenting on a recent article by Jess Phelps and Jessica Owley, ${ }^{1} \mathrm{I}$ argued that historic preservation law poses no significant barrier to removal of Confederate monuments and even provides a useful process within which a community can study and debate the fate of specific statues. ${ }^{2}$ The cultural and legal issues surrounding the removal of Confederate monuments are presented in a surprising and paradoxical form in the controversy surrounding the 1876 Freedmen's Memorial to Abraham Lincoln. Addressing these issues provides an interesting postscript to the seemingly easier questions raised by the removal of monuments to the Lost Cause.

The Freedmen's Memorial, also referred to as the Emancipation Statue, was the first monument to Lincoln erected in Washington, DC. It was paid for by formerly enslaved persons to express gratitude to the slain President for his role in ending slavery. The statue was designed by a white sculptor under the direction of the all-white Western Sanitary Commission. ${ }^{3}$ It depicts Lincoln standing above a kneeling, largely nude African American male. In his right hand, Lincoln holds the Emancipation Proclamation; his other hand is held above the head of the kneeling figure, apparently in the classical pose associated with manumission. The kneeling figure looks up; broken shackles lie on the ground, although iron rings remain on his wrists. The statue stands in Lincoln Park, along East Capitol Street, on a direct axis with the Capitol, as well as with the Washington Monument and the more famous, but later, Lincoln Memorial. Lincoln faces another monument in the park, dedicated in 1974 and depicting noted African American educator Mary McLeod Bethune with two black children. ${ }^{4}$

On June 23, 2020, Delegate Eleanor Holmes Norton issued a press release stating her intent to soon introduce legislation to direct the National Park Service to remove what she termed the "problematic statue" from the park. ${ }^{5}$ She wrote: "Although formerly enslaved Americans paid for this statue to be built in 1876, the design and sculpting process was done without their input, and it shows. The statue fails to note in any way how enslaved African Americans pushed for their own emancipation." ${ }^{6}$ Such complaints about the statute are hardly new. Many viewers consider the statue paternalistic and the

\footnotetext{
${ }^{1}$ Jess R. Phelps and Jessica Owley, Etched in Stone: Historic Preservation Law and Confederate Monuments, 71 Fla.. L. Rev. 627 (2019)(hereinafter "Etched in Stone").

2 J. Peter Byrne, Stone Monuments and Flexible Laws: Removing Confederate Monuments Through Historic Preservation Laws CITE. Efforts to execute the monument began immediately after the war but stretched on for a decade because of financial limitations and design challenges. See Kirk Savage, Standing Soldiers, Kneeling Slaves: Race, War, and Monument in Nineteenth-Century America 90-113 (rev.ed.2018).

${ }^{3}$ The Western Sanitary Commission was a private organization based in St. Louis, formed to provide medical care to Union soldiers, which also provided support to freed people during and after the war. CITE

${ }^{4}$ On the dedication of the Bethune monument, see Erwin Washington, Black Leader's Statue Unveiled, Wash. Post, July 11, 1974, B1.

${ }^{5}$ https://norton.house.gov/media-center/press-releases/norton-to-introduce-legislation-removing-emancipationstatue-from.

${ }^{6}$ Id.
} 
depiction of the freed man demeaning to African Americans. Activists have threatened to topple the statue, as several Confederate monuments have been toppled by direct, extra legal action during protests against police violence against African Americans. Recently, the Park Service has surrounded the Freedmen's Memorial with jersey barriers and a black wire mesh fence, and U.S. Park Police have patrolled the site to discourage vandalism. People with various views stand about discussing and arguing about the fate of the statue. ${ }^{7}$

When I first heard about the movements to take down the Freedmen's Memorial, shortly after finishing my essay on Confederate monuments, my reaction was "No!" I have lived in close proximity to the statue for almost forty years and appreciated it as an expression of joy and thanks from the formerly enslaved people who paid for it. My children had tricycled around it. I had explained its significance to many visiting friends and to new Georgetown law students during orientation tours. And I had thrilled to read historian David Blight's account, leading off his magnificent biography of Frederick Douglass, of the ceremony dedicating it, featuring Douglass's great oration about Lincoln. ${ }^{8}$ Anyone knowledgeable about the history of the memorial must recognize that it is not a monument to white supremacy, like the deplorable Confederate monuments, but a dated affirmation of human dignity and celebration of a crucial advance in our national life. Some African Americans embrace the statue for its historical significance even if no artist would create such an image today.

But the statement of Delegate Norton and of protesters caused me to interrogate my first reaction. The freedman kneels below Lincoln, his equality compromised, as was that of African Americans in 1876 and continuing even today. The Associated Press quoted a Black activist as saying: "It's supposed to represent freedom but instead represents us still beneath someone else. I would always ask myself, "If he's free, why is he still on his knees?'"' Norton's comment that the statue fails to recognize how enslaved people were crucial agents in their own liberation, both in fleeing plantations and in military service, has been echoed by others and seems fair. I began to consider the extent to which my reactions to the prospect of the removal of the Freedmen's Memorial resembled that of white Southerners resisting removal of Confederate monuments - both involve regret at the loss of "heritage" for some but are experienced as demeaning or insulting by many African Americans. I had to ask myself whether my white privilege vouchsafed to me a comfort with the image denied to African Americans.

Can historic preservation law make a contribution to clarifying or resolving competing arguments about the Freedmen's Memorial? It depends. Lincoln Park and therefore the statue are under federal jurisdiction; it is administered and maintained by the National Park Service. Although the Memorial should be considered a contributing structure to the Capitol Hill Historic District, listed on the National Register of Historic Places ${ }^{10}$ and designated under the District of Columbia Historic Landmark and

\footnotetext{
${ }^{7}$ https://www.washingtonpost.com/local/protesters-denounce-abraham-lincoln-statue-in-dc-urgeremoval-of-emancipation-memorial/2020/06/25/02646910-b704-11ea-a510-55bf26485c93 story.html.

${ }^{8}$ David W. Blight, Frederick Douglass: Prophet of Freedom 1-9 (2018). See also https://www.washingtonpost.com/opinions/2020/06/25/ves-freedmens-memorial-uses-racist-imagery-dont-tearit-down/.

${ }^{9}$ https://www.wgbh.org/news/local-news/2020/06/26/protesters-remove-statues-of-slave-kneeling-beforelincoln.

${ }^{10}$ The National Register Nomination Form for the Capitol Hill Historic District can be found here: https://planning.dc.gov/sites/default/files/dc/sites/op/publication/attachments/Capitol\%20Hill\%20Historic\%20Dis trict.pdf. It does not mention Lincoln Park nor the Freedmen's Memorial. Both seem clearly to be protected as
} 
Historic District Protection Act (the "DC Act"), no historic preservation law will probably determine the fate of the statue. Although removal of a structure in a historic district requires a permit under the DC Act, ${ }^{11}$ DC law does not apply to federal actions. Congress is exempt from section 106 of the National Historic Preservation Act ("NHPA"), which thus does not offer any check to Delegate Norton's proposed bill. ${ }^{12}$ If her legislation orders the Park Service to remove the Freedmen's Memorial, the Park Service's action would be deemed ministerial and thus not an agency "undertaking" that triggers the agency's duty to conduct a section 106 study and consultation. ${ }^{13}$ Extra legal action by protestors likely would polarize opinion. ${ }^{14}$

On the other hand, if Congress merely asked the Park Service to consider removing the Freedmen's Memorial or if the Park Service itself proposed to remove it (quite possible during a Biden administration), the process required by section 106 of the NHPA would be mandatory. ${ }^{15}$ That would be either because the Memorial and Lincoln Park contribute to the Capitol Hill Historic District or because either or both are eligible for separate listings in the National Register as landmarks. As noted in the discussion of Confederate monuments, section 106 does not prohibit any action regarding a protected resource but only requires that the final decision be informed by study and consultation. ${ }^{16}$ This process would involve evaluation of the significance of the memorial on its present site to determine whether removing it to another location would have an "adverse effect" on that significance. Such a removal also would have an adverse effect on Lincoln Park, itself a protected resource. This inquiry would be conducted in consultation with so called "consulting parties" and others. The consulting parties at a minimum would be the DC State Historic Preservation Officer, who is supported by a highly killed professional staff, and the federal Advisory Council on Historic Preservation. ${ }^{17}$ The Park Service could invite other consulting parties; in this case, the National Museum of African American History and Culture seems an obvious invitee. Other interested members of the public would be invited to offer comments.

contributing elements to the historic district. Both were created within the district's period of significance. The memorial also should be independently eligible for listing, even though it is a structure "primarily commemorative in nature," because it conveys the significance of the efforts of the formerly enslaved to honor Lincoln.

${ }^{11}$ D.C. Code $\S 6-1105(\mathrm{a})$.

${ }^{12}$ Section 106 imposes preservation duties on federal agencies as that term is defined in 5 U.S.C. §551, which expressly excludes Congress.

${ }^{13}$ See Lee v. Thornburgh, 877 F.2d 1053, 1057-58 (.D.C. Cir. 1989).

${ }^{14}$ Historian Douglas Brinkley told the Washington Post that President Trump is making the extra legal destruction of monuments a central issue in his reelection campaign. "His argument is Main Street values against a crazy wave of anarchy. A lot will depend on how inflamed the monument issue gets. Trump has a vested issue in this. He's actually cheering the anarchists on, daring them to take more down," he said. "It's the one Hail Mary he has in his arsenal kit. He's losing badly, and he doesn't have the kind of numbers he needs to win reelection."

https://www.washingtonpost.com/politics/trumps-twitter-feed-reads-like-a-local-crime-blotter-as-he-stokes-aculture-war/2020/06/30/2e1a48c6-baed-11ea-86d5-3b9b3863273b story.html.

15 54 U.S.C. $\S 306108$.

${ }^{16}$ Stone Monuments at $\mathrm{x}$.

1736 C.F.R. $§ 800.2$. The Advisory Council acts as a consulting party only if it determines its participation is "necessary." Id. §800.2(b)(1). Local governments affected by an undertaking are also entitled to be consulting parties, but Washington, DC, is in the unique position of having the State Historic Preservation Officer be a local government official. It is unclear whether the Mayor would dispatch another District official to be an additional consulting party. 
It seems inescapable that the removal of the Freedmen's Memorial from Lincoln Park would impair the historic significance of the memorial and of the park. The statue was placed intentionally on a ceremonial axis with the most sacred of the nation's civic monuments: the Capitol and the Washington Monument. The ceremony dedicating the memorial was itself an important public event celebrating emancipation and expressing the gratitude of the freed people for the role of the martyred president. The Freedmen's Memorial was the national government's first monument to Lincoln and its first public statue depicting an African American. The ceremony was attended by President Grant, Chief Justice Waite, leading members of Congress and the cabinet, and leading members the capital's African American community. The roster of speakers was capped by a speech by the great orator abolitionist, and symbol of Black liberation, Frederick Douglass. ${ }^{18}$

Douglass gave a brave and historic address providing with nuance a Black perspective on Lincoln, acknowledging that he was the "white man's president" who in his first years in office had been "willing ... to deny, postpone, and sacrifice the rights of humanity in the colored people to promote the welfare of the white people of this country." ${ }^{19}$ But he went on to recognize that Lincoln had embraced emancipation in the face of virulent white racism. Thus, "viewed from the genuine abolition ground, Mr. Lincoln seemed tardy, cold, dull, and indifferent; but measuring him from the sentiment of his country, a sentiment as a statesman he was bound to consult, he was swift, zealous, radical, and determined." 20 Douglass strongly supported the idea of a Freedmen's Memorial, but reportedly adlibbed during the speech (words that did not appear in the printed version of his oration) his concern that "it showed the negro on his knee when a more manly attitude would have been indicative of freedom." ${ }^{21}$ Blight observed that no African American would again address such an august assembly of the leaders of the federal government until the inauguration Barack Obama in 2009. ${ }^{22}$ So the dedication of the statue at that site was an important historical event and the removal the statue would impair its historic significance. Thus, the location of the Memorial in Lincoln Park contributes to its historic significance, so that removing it would be an "adverse effect" both on the significance of the Memorial and of Lincoln Park.

As explained above, the NHPA does not prohibit actions that damage the historic value of any protected resource. While the federal agency engaged in an undertaking must consider and consult about how to avoid or mitigate such harm, it can proceed to remove a resource for any lawful reason. The offense and annoyance that the image of the kneeling freedman inflicts on many (but not all) African Americans and some whites obviously provides an adequate policy basis for removal. ${ }^{23}$ Freed people notoriously were

\footnotetext{
${ }^{18}$ Blight, note 8.

${ }^{19}$ Id., at 6

${ }^{20}$ Id., at 7-8.

${ }^{21}$ See Savage, note 2, at 117-18 (rev.ed.2018). Delegate Norton reference this objection by Douglass in her press release.

${ }^{22}$ Blight, note8, at5.

${ }^{23}$ The members of the Western Sanitary Commission surely did not intend the kneeling figure to disparage African Americans but had the limitations of vision common among white people of their time. The figures are posed in the classical postures evoking manumission. The Commission asked the sculptor to use the likeness of an actual freed man, Archer Alexander, to give immediacy to the statue. Alexander had been protected after fleeing slavery by Commission member and Unitarian minister, William Greenleaf Elliot, the grandfather of poet, T.S. Eliot. Recent DNA research has established that
} 
not involved in the supervision of the design. One can say that while the statue celebrates emancipation, it undermines equality, which mirrors the broader political context near the end of Reconstruction in 1876. A sarcastic epithet directed at the statue captures its deficiencies, "Shine, sir?"24

The Park Service also would need to consider and consult about whether it could avoid removal, primarily by providing greater context to the Freedmen's Memorial in Lincoln Park. David Blight himself has urged that the statue remain, but that new sculpture be commissioned for the park, perhaps expressing contemporary aspects of Black liberation or a statue of Douglass himself. ${ }^{25}$ The Park Service is adept at interpretative materials that can place the statue in its historic circumstances. Such a course could actually enhance the historic significance of the Freedmen's Memorial and of Lincoln Park. But the decision whether to remove the statue would remain with the Park Service. My personal preference would be to retain and contextualize the Freedmen's Memorial, because it honors the gratitude of the freed people to Lincoln and expresses a fraught and hopeful moment before the final abandonment of Reconstruction. Frederick Douglass himself seems to have endorsed the idea of contextualizing the Freedman's Memorial with additional monuments depicting African Americans standing tall. ${ }^{26}$ However, the Park Service probably should follow the considered opinion of African Americans in DC at the end of the consultation process; if they prefer removal that seems the civically responsible course. ${ }^{27}$ Whatever harm the memorial perpetuates is inflicted more on them than on any white person. But the discussion generated by the consulting process and public hearings would provide an important public benefit for all of mutual education and communication.

Assuming that the Park Service decided to remove the statue from Lincoln Park, it would need to consider how to mitigate the harm to the memorial and to the park. While the Park Service would not be obligated to perform any mitigation, the consulting parties surely would use their leverage to advocate for significant mitigation. ${ }^{28}$ The ideal alternative home for the statue would be the National

Alexander is the direct ancestor of Muhammad Ali. https://www.washingtonpost.com/sports/2018/10/02/dna-evidence-links-muhammad-ali-heroic-slavefamily-says/.

${ }^{24}$ Savage, note 2, at 120.

${ }^{25}$ Post

${ }^{26}$ Days after dedication Douglass wrote the New Republican: "The Negro here, though rising, is still on his knees and nude. What I want to see before I die is a monument representing the Negro, not couchant on his knees like a 4-footed animal, but erect on his feet like a man. There's room in Lincoln Park for another monument and I throw out this suggestion to the end that it may be taken up and acted upon."

https://www.washingtonpost.com/history/2020/07/06/archer-alexander-emancipation-memorial-slavery-lincoln/

${ }^{27}$ On June 30, the Boston Art Commission decided to remove a copy of the Freedmen's Memorial that has stood in Park Square since 1879. The sculptor, Thomas Ball, was from Massachusetts. https://www.wgbh.org/hews/localnews/2020/06/30/boston-will-remove-park-square-statue-of-lincoln-freeing-slaves. The statue, known there as the Emancipation Group, has a much more tenuous connection to its site than the Washington memorial has to its. There apparently is no historic preservation law barrier to the removal of the statue in Boston.

${ }^{28}$ The preferred way for an agency to complete the section 106 process is to reach a Memorandum of Agreement with the consulting parties. In the absence of such an agreement, the head of the Park Service would need personally to sign a record of decision describing the decision and failure to reach agreement. 36 C.F.R. $\S 800.7(4)$. In normal times, agency staff do not want to have to bring such decision to the head of their agency. See Sara Bronin and J. Peter Byrne, Historic Preservation Law 164 (2012). 
Museum of African American History and Culture, where it could receive appropriate historical context and interpretation. For Lincoln Park, it would be important to replace the Freedmen's Memorial with a contemporary expression of the roles of the enslaved people, Lincoln, and abolitionists of both races in accomplishing emancipation. Additional art depicting the subsequent history of African Americans would also be appropriate; the Bethune monument, now nearly fifty years old, makes a good start. These efforts themselves would need extensive study in order to preserve the scale and beauty of the historic park.

In the essay on Confederate monuments, I argued that no local government should be forced to keep up public monuments that are offensive to substantial numbers of the community, and that historic preservation law should not and usually will not present a serious obstacle to such removal. I did argue that historic preservation law can provide a decision process though which people can learn more about a controversial monument and its role in their history. Historical documentary maker Ken Burns says that monuments are not so much history as expressions of mythology. ${ }^{29}$ That accords with their treatment under the National Register. But, of course, the act of expressing myth about our history can itself have historical significance. The Freedmen' Memorial certainly conveys that kind of historical significance. Section 106 provides a wholesome process for considering the Memorial's place in our history, its contemporary meaning, and its appropriate disposition. Delegate Norton's bill should direct the Park Service to follow the section 106 process.

${ }^{29}$ https://www.youtube.com/watch?v=W08bTFhuwKs. 